\title{
Multiple use on marginal land: A case for cattle and loblolly pine ${ }^{1}$
}

R.L. Harwell ${ }^{2}$ and C.W. Dangerfield, Jr. ${ }^{3}$

\begin{abstract}
Almost 20 million non-forest, cropland acres in the southeastern United States can be classified as marginal. Demand projections for forest products call for a $40 \%$ increase by year 2030. Recently more land is being logged than regenerated. Land multiple use management, combining trees, cattle and wildlife, adjusts cash flows forward mitigating negative cash flow period associated with conventional forest production. Profit opportunities for smaller landowners are increased. Modification of tree population and spacing, allowing inclusion of hay and pasture, increases net present value (NPV) of agroforestry over traditional forestry. Model results show an increase in NPV from $\$ 554$ to $\$ 948$ per acre when beef cattle are added to loblolly pines on marginal lands.
\end{abstract}

Key words: agroforestry, pines, cattle, NPV, multiple use

\section{Résumé}

Presque 20 millions d'acres de terres de culture non boisées dans les états du sud-est des Etats-Unis peuvent être classifiées comme terres marginales. Les prévisions de la demande de produits forestier prévoient une augmentation de 40 pour 100 d'ici l'an 2030. Ces derniers temps, le niveau d'exploitation forestière est supérieur au niveau de régénération des terres. La gestion intégrée des terres axée sur la plantation d'arbres, l'élevage du bétail et la faune favorise la marge brute d'autofinancement et atténue les pertes à ce chapitre associées à l'exploitation forestière conventionnelle. Les petits propriétaires ont donc la possibilité d'augmenter leurs profits. La modification des peuplements et l'espacement de façon à permettre la culture du foin et de pâturage augmente la valeur actualisée nette (VNA) des activités d'agroforesterie par rapport à la foresterie. Les résultats de modélisation indiquent que l'élevage de bétail et la plantation de pins à encens (Loblolly pine) sur des terres marginales font passer la VNA de $554 \$$ à $948 \$$.

\section{Introduction}

Overproduction, that plague of US agriculture, persists. Wheat production in 1990 was 2.74 billion bushels, nearly matching the record 2.79 billion produced in 1981, and up $35 \%$ from 1989. While world-wide demand for oilseeds is growing slightly faster than supply, demand has slowed in traditional US markets. In feed grains, higher US yields in 1990 more than offset lower harvested area, to post a $4 \%$ increase in production.

US trade prospects have been dampened by greater production in major importing and exporting countries. The recently enacted Farm Bill of 1990 authorizes more than $\$ 40$ billion to be spent over the next five years to help ensure that farm production stays at manageable levels. In the southeastern United States, composed of South Carolina, North Carolina, Georgia, Florida, Alabama, Mississippi, Tennessee and Louisiana, a significant proportion of production comes from lands identified as being "marginal" (USDA 1983).

Marginal land can be identified in terms of profit potential or, in a conservation sense, in terms of erosion potential. According to a recent USDA study, 8 million acres of cropland and pasture in the Upper Coastal Plain and Piedmont Regions of the southeastern United States yield lower returns from their present use than they would in timber production (USDA 1987). The Upper Coastal Plain and Piedmont constitute the two geographical regions lying inland for approximately the first 100 miles from the Atlantic Ocean

\footnotetext{
${ }^{1}$ Paper given at First North American Agroforestry Conference, Univ. of Guelph, Guelph, Ontario, August 1989.

${ }^{2}$ Extension Agricultural Economist, Barre Hall, Clemson University, Clemson, South Carolina 29634-0355.

${ }^{3}$ Extension Agricultural Economist, Coliseum, The University of Georgia, Athens, Georgia 30602
}

and the Gulf of Mexico and extending in a band from Virginia into Louisiana and Mississippi. This area falls well within the natural range of loblolly pine as shown in Figure 1. The Soil Conservation Services lists 11 million acres of non-forest marginal lands in the southeast as having serious, excessive erosion, with additional lands having erosion protection only because they are in pasture, idle, or in uses other than row crops. Currently, over two-thirds of total land in the southeast is in forested uses (USDA 1987).

\section{Timber Supply and Demand}

US Forest Service 1987 assessment projections call for a 40 percent increase in pine pulpwood volume demand by the year 2030. Pine sawtimber volume demand is expected to be 12 percent greater by the year 2030 than at present. With rising real prices for timber expected concomitantly with improving demand, marginal lands in the southeast, defined in terms of profits, would increase to 19 million acres (USDA 1987).

In spite of apparent economic incentives to change from cropping enterprises to timber production, most producers are reluctant to do so. Why is this? A simple comparison of enterprise budgets usually ignores returns to scale, farm program benefits, tax considerations, and changes in land values. Other reasoning has to do with lack of knowledge, lack of experience, tradition (Harwell 1984), and timber market imperfections (USDA 1987).

One common explanation for laggardly timber expansion notes the substantial initial cash outlay required, with returns not anticipated for 15 or more years. The cash flow problems thus created are formidable, exacerbated by the current financial difficulties in agriculture. Also, many producers in a position to make such decisions find 15 to 25 years to be a time well beyond their planning horizons. 


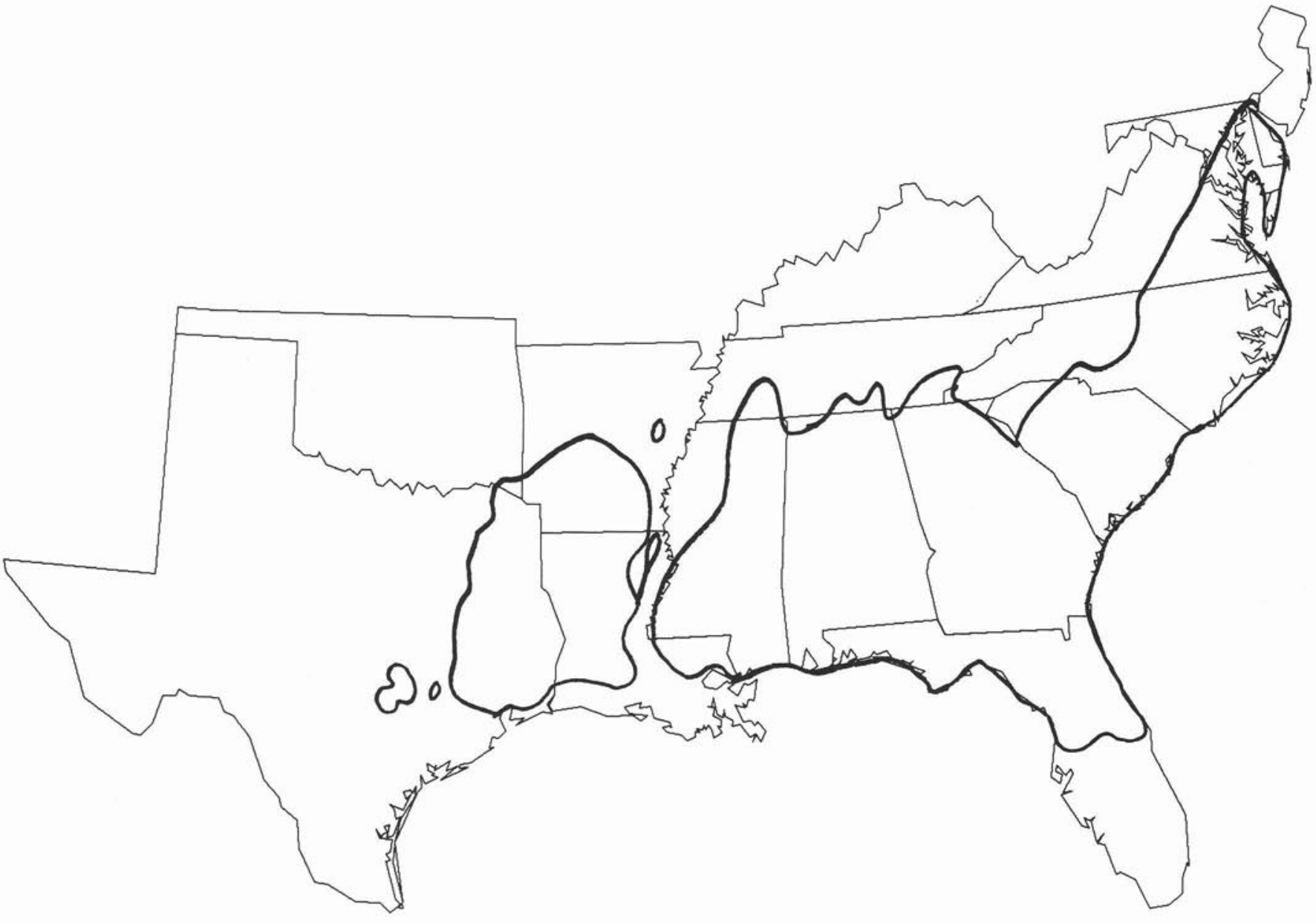

Figure 1. Natural range of loblolly pine in the United States.

\section{Agroforestry}

An emerging body of research supports practical experience that multiple land-use concepts can fit southeastern timber production patterns in a manner practiced in the west for many years (Biswell and Foster 1942, Nieland 1945, Kaufman 1950, Pearson and Whitaker 1973, Grelen and Lowery 1978, Byington et al. 1983). Combining forest, forage, and recreational returns would appear to offer opportunities for improving cash flows during the initial years of a timber investment, and perhaps throughout the life of the enterprise.

Historical evidence overwhelmingly incidates that Indians managed their forest resource by fire to furnish grazing for buffalo and elk (Hansbrough 1980). When Ponce de Leon and other explorers brought cattle and hogs to the new world, they found "openness of the woods", "vast prairies", and "extensive tracts covered only by grass". The practice of grazing open timberlands by the colonists was so prevalent that a whole set of laws and customs became established, predating the open range era of the west by many years (Lee 1980).

Foresters have traditionally been hesitant about recommending forest grazing, citing as reasons damage to young trees, competition from wildlife, unsuitable land ownership patterns, unfamiliarity with "'good examples", and low financial returns (Sullivan and Matney 1980). The biological feasibility of multiple land use in southeastern forests has been researched extensively since the early 1940's. Lewis et al. (1982) list widespread examples of successful agroforestry management scenarios that support the research findings.

Investigations on the economic practicality of forest-forage systems are less common, but recent endeavors suggest that under good management the physical resources exist to improve profit and cash-flow potentials. Bond and Campbell developed budget information necessary for multiple land use operations in Louisiana slash pine forests in 1951. Pearson and Whitaker explored returns from various grazing rates in longleaf pine in 1972 and found them all to be positive under good management. More recently, Haney (1980) has used extensive modeling to show the economic attractiveness of integrated land management on returns to investment in timber and forage/beef production in the coastal plain of Virginia. Lundgren et al. have explored the economics of various timber/grazing management practices and have examined the profitability of rotational grazing schemes.

\section{Purpose}

If conversion of marginal southeastern cropland to timber production would correct a mis-allocation of resources, and thus add to long-term national and regional welfare, as suggested by Fedkiw (1984), then multiple land use as a conversion tool has obvious policy implications. The specific objective of this paper is to compare the financial/cash-flow impact of converting marginal cropland to timber with that of converting marginal cropland to a multiple land use, including timber. 
A secondary purpose is to provide a model whereby conversion of marginal land to multiple use can be evaluated for enterprises other than those presented here and for locations other than the southeastern United States. Such conversions may include livestock enterprises where forage production is the major focus, i.e., dairy cattle, sheep, goats, etc. Applicable tree crops may include those produced for wood fibre as well as fruit and nut trees. Of primary importance is that livestock access to the tree growing area be limited during early tree growth to avoid tree damage from grazing or trampling.

An owner of marginal cropland interested in making an enterprise change would be concerned with: (1) the expected profitability of the contemplated investment, which may include the level of returns, asset appreciation, risk, and tax effects; and (2) the distribution of returns and their bearing upon cash flows. Other considerations relating to the utility of owning cropland are beyond the scope of this paper.

\section{Methodology}

The model examines the economic effects of using an agroforestry approach to the conversion of marginal cropland to timber. YIELDplus (V1.1c), a computerized simulation model developed by the Tennessee Valley Authority (Hepp 1988), is designed to predict growth and yield for stands of timber described by an array of production specifications. As a secondary feature, the model analyzes the financial consequences of a timber investment scenario based on the specification of costs and returns data including income tax information. The model is useful in refining a management plan and has obvious applications in timber investment analysis across time.

The upper coastal plains of Georgia was chosen as a representative site suitable for agroforestry application. The specific area utilized in the model carries a loblolly pine site index of 60 feet at 25 years, a soil capability placing the site in the upper range of marginal lands. For baseline data, loblolly pines were planted on marginal cropland in $8^{\prime} \times 8^{\prime}$ spacing, a population of approximately 650 trees per acre. The stand was thinned at 15 years to a residual basal area of 80 sq. $\mathrm{ft}$. per acre and clearcut at 25 years, a planning horizon more easily envisioned by row crops oriented producers. Heavier thinning practices were chosen to open up the tree canopy and move cash flows forward. Optimum profit plans would require considerably longer rotations, but the baseline chosen is profitable.

Prices for pulpwood (5" -9" DBH), chip-N-saw (10"-12" DBH), sawtimber (13" $-19^{\prime \prime}$ DBH), and peeler poles ( $>19^{\prime \prime}$ DBH) were estimated to be $\$ 24.00$ and $\$ 52.50$ per cord and $\$ 170$ and $\$ 185$ per MBF (Timbermart South 1988), respectively. The chip-N-saw market provides improved revenue through the sale of an intermediate size wood product between pulpwood and sawtimber. These prices were projected to rise at $2 \%$ real inflation per year, above a projected 3\% general inflation (USDA 1987).

Cattle grazing was introduced into the model with minor modifications to tree growth. A $4^{\prime} \times 8^{\prime} \times 40^{\prime}$ spacing (454 trees/acre) allowed bahia or bermuda grass to be planted and maintained in the stand (Lewis 1984, 1985, 1987). The trees were spaced $4^{\prime}$ apart in the row with two rows $8^{\prime}$ apart and then a $40^{\prime}$ wide middle. Annual fertilization of the grass enhanced tree growth (Lewis 1985, 1987). This increased
Table 1. Per acre woodflow summary report, modeled beginning $1988^{1}$.

\begin{tabular}{lccccc}
\hline & $\begin{array}{c}\text { Trees } \\
\text { per acre }\end{array}$ & $\begin{array}{c}\text { Site }^{2} \\
\text { index }\end{array}$ & $\begin{array}{c}\text { MBF }^{\mathbf{3}} \\
\text { Timber }\end{array}$ & $\begin{array}{c}\text { Cords } \\
\text { Pulpwood }\end{array}$ & $\begin{array}{c}\text { Total cords } \\
\text { Woodflow }\end{array}$ \\
\hline Forestry & 650 & 60 & 2.95 & 37.51 & 49.10 \\
Agroforestry & 454 & 65 & 6.73 & 28.44 & 53.43 \\
\hline
\end{tabular}

'Southeastern U.S., upper coastal plains, loblolly pine site, thinned at age 15 and clear-cut at 25 years.

${ }^{2}$ Average height of dominant trees at 25 years.

${ }^{3}$ Thousand board feet, Scribner rule.

growth effect was approximated by raising the site index from 60 to 65 feet at 25 years, increasing total wood yield about 8.8\% (Hepp 1988).

Although not specifically designed to accommodate enterprises other than timber production, YIELDplus allowed the addition of other enterprise investment costs, recurring expense items, and income streams into the cash flow and categorized them for proper income tax treatment. Published budgets by Clemson University and the University of Georgia Extension provided input data for establishing and maintaining forage crops and for investment and annual costs related to the cow herd. Grazing forage for 50 brood cows (a two-bull unit, which converted into 71 animal units) was provided by 134 acres of forested bahia and bermuda pasture and an additional 66 acres of forested bermuda pasture, designed to provide hay and supplemental grazing (Byrd 1983, Lewis et al. 1982). Pasture establishment and maintenance costs were allocated on a per acre basis to the agroforestry acres.

In a traditional beef cow-calf enterprise approximately 75 acres of total land are required to supply forage needed for a 50-cow herd, a 1.5 acre per cow stocking (Brown 1988). In an agroforestry enterprise, budget values allow a stocking rate of 4 acres per cow (Lewis et al. 1983, 1985, 1987). To simulate an extensive approach to beef production, pasture establishment and maintenance costs were spread over 200 acres instead of 75 . Also, the adoption of a 25-year planning horizon allowed smoothing of cattle cycle prices for an average weighted price of $\$ 76.85$ per cwt (Brown and McKissick 1988).

Commonly used investment analysis criteria, where the distribution of cash flows is important, are the net present value method (NPV) and internal rate of return (IRR) method (Barry et al. 1983). Using some specified minimally acceptable compound rate of return, both procedures overcome potentially erroneous investment decisions made by looking at payback or simple rate of return methods. NPV and IRR measurements were used on the agroforestry assumptions listed, with an assumed discount rate of $8 \%$ (USDA 1987).

The model calculated NPV and IRR both before and after taxes. The marginal tax bracket was $28 \%$ and capital gains were taxed on a $100 \%$ proportion under provisions of the Tax Reform of 1986.

\section{Results}

Table 1 shows yields of pulpwood and sawtimber on the site, if used solely for timber production, at 37.51 cords of pulpwood and 2.95 thousand board feet (MBF) sawtimber per acre, respectively. Changing to an agroforestry enterprise entailed changing the tree spacing from $8^{\prime} \times 8^{\prime}$ to $4^{\prime} \times 8^{\prime} \times 40^{\prime}$ spacing and raising the site index from 
Table 2. Financial profitability analysis, per acre, modeled beginning $1988^{1}$.

\begin{tabular}{|c|c|c|c|c|c|}
\hline & $\begin{array}{c}\text { Net cash } \\
\text { flows }\end{array}$ & $\begin{array}{c}\text { Before } \\
\operatorname{tax} \text { NPV }^{2}\end{array}$ & $\begin{array}{c}\text { After } \\
\operatorname{tax} \text { NPV }\end{array}$ & $\begin{array}{c}\text { Before } \\
\operatorname{tax} \text { IRR }^{3}\end{array}$ & $\begin{array}{c}\text { After } \\
\text { tax IRR }\end{array}$ \\
\hline & \multicolumn{3}{|c|}{$\longrightarrow(\$)-$} & \multicolumn{2}{|c|}{$-(\%)-$} \\
\hline Forestry & 1154.38 & 553.59 & 719.32 & 16.4 & 16.4 \\
\hline with $v$ & 1206.38 & 584.28 & 746.76 & 17.2 & 17.1 \\
\hline Agroforestry $\mathrm{A}^{4}$ & 1968.77 & 948.02 & 1139.28 & 23.1 & 22.8 \\
\hline with wildlife & 2020.77 & 978.62 & 1166.72 & 24.5 & 24.0 \\
\hline Agroforestry $\mathrm{B}^{5}$ & 2145.05 & 1021.69 & 1204.71 & 26.4 & 25.8 \\
\hline with wildlife & 2197.05 & 1052.30 & 1232.14 & 28.2 & 27.4 \\
\hline
\end{tabular}

'Southeastern U.S., upper coastal plains, loblolly pine site, thinned at age

15 and clear-cut at 25 years.

${ }^{2} \mathrm{Net}$ present value.

${ }^{3}$ Internal rate of return.

${ }^{4}$ Cattle enterprise considered as new investment.

${ }^{5}$ Cattle enterprise considered as old investment.

60 to 65 (height of dominant and co-dominant trees in feet at age 25 years). The net effect increased woodflow to 28.44 cords pulpwood and 6.73 MBF sawtimber, some $8.8 \%$ increase in total cord equivalent volume.

Measures of profitability for the timber enterprise and for agroforestry combinations involving cattle and wildlife income are given in Table 2.

Examinations of model results show the timber operation to be profitable, both before and after income taxes are considered. The per acre net present value (NPV) of anticipated returns through 25 years, discounted at $8 \%$, is $\$ 553.59$ before taxes and $\$ 719.32$ after taxes. The after tax NPV returns are larger than before tax NPV returns due to the tax program effects on forestry income. These provisions include the $10 \%$ investment tax credit on reforestation expenses and complete amortization of allowable expenses over a 7-year period. Also, because interest expenses are deductible with forestry investments, the after tax discount rate is correspondingly lower than the before tax discount rate (In this case 8.0 and $5.8 \%$, before and after tax respectively). Corresponding internal rates of return are $16.4 \%$ and $16.4 \%$, respectively. The addition of an annual $\$ 2.00$ per acre wildlife lease increased the after-tax NPV by over $\$ 27$ and the after-tax IRR by $0.7 \%$.

The remaining values in Table 2 addresses two alternative scenarios, Agroforestry A and Agroforestry B. When a beef cattle enteprise must be begun in its entirety, the area must be fenced, pastures planted, supporting facilities constructed, and a cow heard assembled. Such a scenario is shown as Agroforestry A in Table 2. For a cattleman interested in converting cropland to multiple use, but with an existing investment in animals, pastures, and handling facilities, Table 2 presents Agroforestry B.

As further shown in Table 2, there is an economic incentive to consider agroforestry in the resource area under consideration. An initial beef cattle investment is profitable, and compliments the profits generated by the forestry component. In Agroforestry A after-tax NPV and IRR rise from $\$ 719.32$ and $16.4 \%$ to $\$ 1139.28$ and $22.8 \%$, respectively. For Agroforestry B continuing a cattle enterprise rather than beginning a new one, is more attractive to the extent that it improves cash flow of the agroforestry enterprise. The corresponding after tax NPV and IRR are \$1204.71 and $25.8 \%$, respectively. In all cases, the wildlife lease is helpful. but not necessary to ensure profitability.
Table 3. Annual net returns and costs from cow-calf and forage operations, dollars per acre, southeastern U.S., modeled beginning 1988.

\begin{tabular}{|c|c|c|c|}
\hline Enterprise & Revenues & Forage costs & Net income \\
\hline Agroforestry $A^{2}$ & $\$ 26.33$ & $\$ 13.27$ & $\$ 13.06$ \\
\hline Agroforestry $\mathrm{B}^{3}$ & $\$ 31.66$ & $\$ 11.41$ & $\$ 20.25$ \\
\hline
\end{tabular}

${ }^{1}$ Southeastern U.S., upper coastal plains, loblolly pine site, thinned at age 15 and clear-cut at 25 years.

${ }^{2}$ Cattle enterprise considered as initial investment.

${ }^{3}$ Cattle enterprise considered as continuing investment.

\section{Conclusions}

As noted earlier, agroforestry is gaining increased acceptance among southern timber operators. Research, both biological and economic, generally supports the enterprise. Results shown above are strongly positive.

The difference calculated between annual returns from the cow-calf operations and annual costs attributed to beef cattle and forage maintenance provides an annual per acre net income of $\$ 13.06$ and $\$ 20.25$ for the Agroforestry A and B enterprises, respectively, Table 3 . Net returns are to land, labor, management and risk. Clearly, these costs and returns figures point to an opportunity for profit.

Most agroforestry enterprises on which research is reported operate on a relatively large scale (Lewis et al. 1982). The enterprise budgets used in the model also indicate an economic opportunity for small operators.

Declining national beef cattle inventories since 1981 reflect that, until very recently, incomes from most cow-calf operations have been less than attractive. This has led to more extensive land management schemes designed to reduce per acre costs; witness the current thrust toward research in sustainable agriculture. Agroforestry, a further variation of multiple use, is an example of such management. Historically, extension budgets have reflected a more intensive management scheme designed to extract higher per acre profits, with more emphasis on purchased capital inputs. Many such budgets may need reexamination.

Finally, more research is needed on the economics of multiple use forestry, particularly on farm operations of smaller scale. The concepts are little different from typical farm management approaches and an abundance of data and methodological support are available.

\section{References}

Barry, P.J., J.A. Hopkins and C.B. Baker. 1983. Financial management in agriculture. Interstate Printers and Publishers, Inc., Danville, IL, Third Ed.

Biswell, H.H. and J.E. Foster, 1942. Forest grazing and beef cattle production in the Coastal Plains of North Carolina, N.C. Agric. Exp. Sta., Bul. 334, pp 3-7, March.

Bond, W.E. and R.S. Campbell. 1951. Planted pines and cattle grazing - a profitable use of southwest Louisiana's cut-over pine land. Louisiana For. Comm., Bul 4.

Brown, R.E. and J.C. McKissick. 1988. Cow-calf budget, south Georgia. Sec. III, p. 9, Decisions for profit. Ext. Agric. Econ., Univ. Georgia, Athens, GA 30602.

Byington, Evert, D. Child, N. Byrd, S. Halverson, H. Pearson and F. Horn. 1983. Management of southern US farms for livestock grazing and timber production of forested farmlands and associated pasture and range lands. Winrock International, Morriliton, AR, pp. 4-17, June.

Byrd, N.A. and C.E. Lewis. 1983. Managing pine trees and bahia grass for timber and cattle production, Gen. Rep., USDA For. Serv., R8-FR 2, October. 
Fedkiw, J. 1984. An economic outlook for grass, cattle, trees, and wildlife hunting in the southeast. Paper given at the Southeastern Grazing Lands and People Conference, Atlanta, Georgia, December.

Grelen, H.E. and R.E. Lowrey. 1978. Herbage yield related to basal area and rainfall in a thinned longleaf plantation. USDA For. Serv., South. For. Exp. Sta., Res. Note SO-232.

Haney, H.L., Jr. 1980. Economics of integrated cattle-timber land use. Proc. Southern Forest Range and Pasture Symposium, New Orleans, Louisiana, March.

Hansbrough, T. 1980. Integrated use of the southern forest range: A sociological perspective. Proc. Southern Forest Range and Pasture Symposium, New Orleans, Louisiana, March. pp. 59-65.

Harwell, R.L. 1984. Economic factors affecting grazing lands utilization in the southeastern United States. Paper presented at the Southeastern Grazing Lands and People Conference, Atlanta, Georgia, December. p 3.

Hepp, T.E. 1988. A users' manual for YIELDplus, timber yield forecasting and planning tool, ver. 1.1c, Tennessee Valley Authority, Forest Resources Development, Norris, Tennessee 37828, August.

Kaufman, C.M. 1950. Forest grazing in the piedmont. Tech. Rep. No. 2. Sch. For. NC State Coll., May.

Lee, J.C. 1980. Integrated use in the South: A biological perspective. Proc. Southern Forest Range and Pasture Symposium, New Orleans, Louisiana, March.

Lewis, C.E. and H.A. Pearson. 1987. Agroforestry using tame pastures under planted pines in the southeastern United States. In Agroforestry: Realities, Possibilities, and Potentials. Henry L. Gholz, (ed.) Martinus Nijhoff Publishers, Dordrecht, The Netherlands.

Lewis, C.E., G.W. Tanner and W.S. Terry. 1985. Double vs. single row pine plantations for wood and forage production, South J. of Appl. For. 9:1.
Lewis, C.E., G.W. Burton, W.G. Monson, and W.C. McCormick. 1983. Integration of pines, pasture, and cattle in South Georgia, USA. Agroforestry Systems. Martinus Nijhoff/Dr. W. Junk Pub., The Hague, The Netherlands. Vol. 1.

Lewis, C.E., G.W. Tanner and W.S. Terry. 1982. Multiple-use management practices for the flatwoods. In Proceedings, Impacts of intensive forest management practices symposium. Univ. Florida.

Lundgren, G.K. 1983. An economic analysis of forest grazing on four timber management situations. South. J. Appl. For. 7(3).

Nieland, L.T. 1945. Timber-grazing-game. Univ. Florida Agric. Ext. Serv. undated and unnumbered.

Pearson, H.B. and L.B. Whitaker. 1973. Returns from southern forest grazing. J. Range Manage. 26: 85-87.

Sullivan, A.D. and T.G. Matney. 1980. Trade-offs in wood and forage production. Proc. Southern Forest Range and Pasture Symposium. New Orleans, Louisiana, pp. 67-74. May.

Timber Mart South. 1988. Stumpage price mart, Standing timber, Box 1278, Highlands, NC 28741, November, December 1987, January.

U.S. Department of Agriculture. 1983. Conversion of southern cropland to southern pine tree plantings. Off. Budg. and Program Anal. December.

U.S. Department of Agriculture. 1985. Annual Agricultural Outlook Conference. "Commodity speeches for Wednesday, November 28, 1990: selected remarks."

U.S. Department of Agriculture. 1987. Grain Stocks Report, Statistical Reporting Service, June.

USDA Forest Service. 1983. 1983 Supplement to the 1979 Assessment of Forest and Rangeland Resources.

USDA Forest Service. 1987. The South's Fourth Forest, Alternatives for the Future. J. Lamar Beasley, Project Chairman. Forest Resource Rep. No. 24. June. pp. 512.

\section{Membership Dues 1991-1992}

\footnotetext{
Active Membership

1 st and 2 nd year after graduation

(grad 1990, grad 1991)

Other new members for first year

Married or equivalent, second member only

All other active members

\section{Other Memberships}

Members having retired status, prior to 1990-91

who wish to receive the Forestry Chronicle

Members having retired status, prior to 1990-91,

who do not wish to receive the

Forestry Chronicle

Members granted retirement status subsequent to $1989-90$

Student Members

Sustaining Individuals (CIF Members)

Sustaining Corporate
}

National
Dues

Section Dues

$\$ 82.00$
$\$ 82.00$
$\$ 82.00$
$\$ 114.00$

$\$ 336.00$
$\$ 0.00$

$\$ 336.00$

$\$ 336.00$
$\$ 38.00$
$\$ 240.00$

$\begin{array}{ll}\text { AL } \$ 8.00 & \text { NW } \$ 12.00 \\ \text { CC } \$ 8.00 & \text { Students } \$ 5.00 \\ \text { CH } \$ 8.00 & \text { OK } \$ 5.00 \\ \text { CO } \$ 10.00 & \text { OR } \$ 7.00 \\ \text { CR } \$ 8.00 & \text { OV } \$ 16.00 \\ \text { LW } \$ 13.00 & \text { PA } \$ 8.00 \\ \text { MB } \$ 10.00 & \text { RM } \$ 10.00 \\ \text { MR } \$ 00.00 & \text { SK } \$ 10.00 \\ \text { ND } \$ 10.00 & \text { SN } \$ 8.00 \\ \text { NO } \$ 5.00 & \text { SO } \$ 20.00 \\ \text { NS } \$ 10.00 & \text { Students } \$ 20.00 \\ & \text { VA } \$ 10.00 \\ & \text { VI } \$ 5.00\end{array}$

Upon written application, spousal members of Active Members may have the dues of one of them reduced by an amount determined annually. Spousal members are members of the same Section who are living together as spouses and using the same mailing address.

The Institute year runs from July 1 to June 30. Applications dated after January 1 will be charged half dues for that Institute year. Applications dated after April 1 will be charged no dues for that Institute year. 